Stručni rad

DOI: $10.17234 /$ Croatica.42.3

UDK: 811.163.42(497.6)(091)

81:272-789.3(497.6)Pranjković, I.

Primljen: 17. XII. 2017.

Prihvaćen: 27. I. 2018.

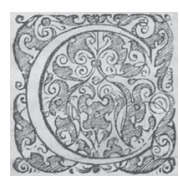

\title{
IVO PRANJKOVIĆ O JEZIKU BOSANSKIH FRANJEVACA
}

\author{
Ekrem Čaušević \\ Filozofski fakultet Sveučilišta u Zagrebu \\ Odsjek za turkologiju, hungarologiju i judaistiku \\ ekrem.causevic@ffzg.hr
}

U članku se govori o znanstvenome radu Ive Pranjkovića na proučavanju jezika bosanskih franjevaca. Njegove radove i knjige o jezičnim i jezično-stilskim karakteristikama franjevačkih kronika i književnih djela autor smatra golemim i dragocjenim doprinosom hrvatskoj filologiji i proučavanju tradicije hrvatskoga jezika koja je do kraja 19. st. gotovo isključivo vezana za djelatnost franjevaca Bosne Srebrene.

Ključne riječi: Ivo Pranjković, jezik bosanskih franjevaca, franjevačko spisateljstvo na hrvatskom jeziku

\section{PRANJKOVIĆEVI DOPRINOSI HRVATSKOMU JEZIKOSLOVLJU}

Raspon znanstvenih interesa prof. Ive Pranjkovića tematski je vrlo širok. Granice njegova impresivnog znanstvenog opusa s jedne strane omeđuju radovi o suvremenome hrvatskom jeziku, a s druge pak radovi o povijesti hrvatskoga jezika i jezikoslovlja. Premda se katkada može učiniti da su u fokusu Pranjkovićeva zanimanja sintaksa i semantika, gramatičke kategorije, kategorijalna značenja i sintaktičko-semantički odnosi koordinacije i subor- 
dinacije, u njegovu je opusu i značajan broj radova o fonologiji i akcentologiji hrvatskoga jezika, povijesnoj i suvremenoj leksikografiji, normativnoj, standardološkoj i pravopisnoj problematici i dr. U treću skupinu njegovih znanstvenih radova mogli bi se uvrstiti tematski raznolikiji, pretežno lingvostilistički i sociolingvistički radovi. U njima se autor bavi lingvostilističkim statusom standardnih jezika na novoštokavskoj osnovici, funkcionalnim stilovima hrvatskoga standardnog jezika, jezično-stilskim osobitostima djela hrvatskih pisaca itd. Iza ovoga šturog i nepotpunog nabrajanja Pranjkovićevih znanstvenih postignuća kriju se deseci izvrsnih radova koji upotpunjuju njegovu opsežnu i bogatu bibliografiju.

Ponekad se dogodi da na skupu u čast znanstvenika iza kojega je velik i raznovrstan opus neki njegovi tematski specifični radovi ostanu u sjeni njegovih često citiranih knjiga i članaka o "aktualnijim" temama. Zbog toga će se autor ovoga kratkog teksta, dakako ne kao kroatist jer to nije po struci, nego kao filolog koji se i sam bavio jednim segmentom franjevačke jezikoslovne baštine, osvrnuti na Pranjkovićev iznimno plodan rad na jeziku bosanskih franjevaca.

Pozivajući se na istraživanja prethodnika i kolega kroatista koji su pisali o istoj temi, ali i na rezultate svojih istraživanja, Pranjković obrazlaže zbog čega je jezik franjevačke književnosti Bosne Srebrene 17. i 18. st. iznimno važan za povijest hrvatskoga jezika. U vezi s tim on ističe sljedeće (citiram):

1. da je hrvatska standardnojezična tradicija gotovo isključivo (zapravo sve do kraja 19. st.) vezana za djelatnost franjevaca Bosne Srebrene;

2. da su franjevci Bosne Srebrene izgradili izrazito prepoznatljiv, u velikoj mjeri ujednačen i funkcionalno polivalentan standardnojezični uzus, i na fonološkoj, i na morfonološkoj, i na grafijskoj, i na pravopisnoj, i na sintaktičkoj, i na leksičkoj razini;

3. da je taj uzus izgrađen u velikoj mjeri uz oslanjanje na (novo)štokavske govore u $\mathrm{BiH}$, pretežno na govore srednje Bosne (ikavskoga ili ijekavskoga tipa);

4. da je na sintaktičkoj i leksičkoj razini na taj uzus u prilično velikoj mjeri utjecala književnost hrvatskoga priobalja, i dalmatinska (čakavska) i dubrovačka (štokavska), dijelom čak i kajkavska književnost (u leksi$\mathrm{ku}$ ), ali isto tako i sintaktički ustroj te leksik latinskoga i talijanskoga jezika (uz razmjerno veliku zastupljenost turcizama);

5. da je standardnojezični uzus koji su u BiH, ali i u Hrvatskoj, najvećim dijelom oblikovali franjevci Bosne Srebrene u vrlo velikoj mjeri utjecao na (konačnu) standardizaciju i kodifikaciju hrvatskoga jezika koja 
je provedena krajem 19. st., te da je utjecao i na oblikovanje ostalih idioma standardnojezičnog tipa koji su izgrađeni na osnovi štokavskog narječja. ${ }^{1}$

6. da su [franjevačka] djela najraznovrsnijega sadržaja u standardizacijskim procesima, posebice onima koji su bili vezani za puk i njegovo (i jezično) prosvjećivanje odigrali važniju ulogu negoli estetski neusporediva i neprocjenjivo vrijedna književnost starog Dubrovnika. ${ }^{2}$

Navedena zapažanja implicitno govore i o neprocjenjivoj vrijednosti franjevačke spisateljske baštine o kojoj je u proteklim desetljećima objavljen velik broj preglednih, stručnih i znanstvenih radova u Hrvatskoj te Bosni i Hercegovini.

\section{PRANJKOVIĆEV RAD NA FRANJEVAČKIM TEKSTOVIMA}

Profesor Pranjković svoje radove o djelima franjevaca Bosne Srebrene koncipira po obrascu koji olakšava usporedbu autora i jezičnih primjera preuzetih iz njihovih djela. Njegovi se znanstveni radovi sastoje od cjelina u kojima su obrađeni povijesni okvir, biografski podaci, spisateljska djelatnost, latinična grafija, pravopisna načela koja su zastupali pojedini autori, fonološka, morfonološka (tvorbena) razina, morfologija, sintaksa, red riječi i leksik svakoga pisca. Jezična i jezično-stilska analiza temelji se na primjerima čiji je ukupan broj teško i procijeniti.

Svatko tko je pisao slične filološke radove dobro zna koliko znanja, energije, istraživačkoga mara, predanosti i vremena treba da se ti primjeri samo popišu. Autor ovoga skromnog priloga iz osobnoga "predračunalnog" iskustva zna da pomno čitanje opsežnijega teksta završava stotinama kartica s primjerima koje, nakon višemjesečnoga rada, treba klasificirati i analizirati pa tek onda pristupiti pisanju. Čak i da su ti radovi nastajali u novije vrijeme, jasno je da se Pranjkovićevo istraživanje starih franjevačkih tekstova iz razumljivih razloga ne bi moglo ni ubrzati ni olakšati internetskim pretraživanjem korpusa suvremenoga hrvatskog jezika.

U ovome članku ukratko ću se osvrnuti na samo jedan mali segment Pranjkovićeva opisa sintakse franjevačkih spisatelja, ${ }^{3}$ točnije, na neke glagol-

\footnotetext{
Ivo Pranjković, Franjevačko spisateljstvo na hrvatskome jeziku, str. 27.

Ivo Pranjković, Hrvatski jezik i franjevci Bosne Srebrene, str. 6-7.

Izbor nije slučajan jer su Pranjkovićevi radovi o sintaksi jedan od njegovih najvećih i najzapaženijih doprinosa hrvatskome jezikoslovlju.
} 
ske oblike i sintagme koje se ne susreću u suvremenome hrvatskom jeziku, te na autorova zapažanja o leksiku, s nakanom da malim brojem primjera predočim njegov pristup filološkoj analizi tih tekstova.

U Pranjkovićevim dvjema spomenutim knjigama na više je mjesta istaknuto da sintaktička obilježja jezika franjevačkih pisaca ovise o vrsti djela (dakle o tome je li riječ o ljetopisu, teološkom ili književnom tekstu ili pak prijevodu) te o vremenu u kojemu je to djelo nastajalo. Nadalje da se u starijim tekstovima susreću kalkovi s latinskoga (češći slučaj) i talijanskoga da bi u kasnijem razdoblju (18. i posebice 19. st.), u manje zahtjevnim tekstovima i književnim djelima nadahnutima pučkom usmenom književnošću, sintaksa poprimila obilježja narodnoga jezika.

Pranjković izrijekom kaže da se u djelima franjevaca Bosne Srebrene često susreću sintaktički kalkovi, ali i "neobične konstrukcije" za koje se ne može uvijek precizno utvrditi jesu li nastale pod utjecajem stranoga jezika. Iako se iz razumljivih razloga te "neobične konstrukcije" danas ne susreću u hrvatskome standardnom jeziku, ponekad se čine toliko začudnima i na svoj način lijepima da bi i u suvremenome književnom jeziku, posebice u prijevodu starijih tekstova, neke od njih mogle poslužiti kao izvrsna stilska pričuva.

Od danas neproduktivnih konstrukcija nastalih sintaktičkim kalkiranjem spomenut ću one koje su se jednome nekroatistu, dakle autoru ovoga teksta, još pri prvome susretu s franjevačkim ljetopisima činile neobičnima i zanimljivima. U takve uvrštavam i sintagme s nekoć produktivnim nesročnim atributom (imenicom u genitivu) koji prethodi upravnome članu. Navest ću samo neke od brojnih Pranjkovićevih primjera: ženske bludnice sin; udariše na nevirnoga despota kotare; gusaka i pataka veliko mloštvo (35) ${ }^{4}$ (Lašvanin). Bliskoznačne su im konstrukcije s prijedlogom od s imenicom u genitivu, nastale pod utjecajem talijanskoga, npr. vrime od razuma, obličje od kruha; poglavar od Žudija; vojvoda od puka (33) (Lašvanin); misto od boja; stajališta od put križa; General od Propagande (103) (Baltić).

Pranjković na velikome broju primjera analizira i danas "neobična značenja prijedloga", poziciju atributa iza imenice (utjecaj talijanskoga), konstrukcije nastale doslovnim prevođenjem s latinskoga jezika (odnosne zamjenice i/ili prilozi dolaze na početak rečenice) te rečenice s predikatnim glagolom na kraju (utjecaj latinskoga jezika), npr.:

$4 \quad$ Brojevi u zagradi upućuju na stranicu knjige Hrvatski jezik i franjevci Bosne Srebrene. Iz te su knjige navođeni primjeri koje je autor Ivo Pranjković zapisivao radeći na franjevačkim ljetopisima i drugim tekstovima. 
ništa neznadiaše od rešenja; jedan drugova pukne iz puške (103) (Baltić); izgori sutiški manastir van izvan crkve; iz priko Crnog mora; dojde s vojskom na pomoć Zadru (33); na službu crkovnu; tri odžaka kadinska i ajanska (34) (Benić); ...Od koga čovika nemilostivijega zemlja nije rodila; Jakov od Mešopotamije u zemlju kananejsku pride (35); Neron šesti rimski car posta (29) (Lašvanin).

Danas nam se čini stilogenom i nekoć česta uporaba preteritalnih glagolskih vremena (aorista, pasivnoga aorista i imperfekta) te futura drugoga u značenju pretprošlosti. I uporabu tih glagolskih vremena Pranjković predočuje brojnim primjerima, među ostalima i ovim:

nošaše, zvaše, dilovaše (19) (Dobretić); rodi se u Jeruzolimu; (Turci) porobiše, popališe, odvedoše, uzeše mloge gradove; izgori novi palac cesarov u Вес̌u (27) (Lašvanin); bi vržen među lave; poklani biše svi (28); Turci opet u Italiji mloga zla i štete učiniše (36) (Lašvanin); (usilnik) ljude mučaše; dičicu od sise materine otimahu i sicijahu ter psom bacahu (28) (Margitić); da se ne budu izbavili do malo, umrli bi; da se isti ne bude bojo vezira, zado bi veliku muku fratrim (93) (Baltić).

Pranjković navodi i mnoge primjere za uporabu krnjega infinitiva ili supina, raznovrsne infinitivne konstrukcije uz glagol činiti te participijalne konstrukcije "nastale pod utjecajem latinskoga jezika", među njima i one "koje se ne slažu u licu s dijelom rečenice na koji se odnose":

zaprimitga; zapodilit Sakramente (20-21) (Dobretić); za dobit dobar glas kod cara; čini sikirom izsić, brodove i brodare čini sažeć ognjem (30); učini se fratrom (31); Selim car, približavajući se zima, ode u Carigrad (32) (Lašvanin); donja dva čovika radeća nagrdi; Soldati htijući mu pušku oteti, on ju opali (106) (Baltić).

Govoreći o leksiku, Pranjković konstatira da su u njemu zastupljeni regionalizmi različitoga tipa, leksik štokavskih govora bosanskih Hrvata, elementi koji se doimaju kao arhaizmi, historizmi, neologizmi, kajkavizmi, turcizmi, latinizmi i talijanizmi (ti se odnose na crkvene i teološke pojmove), zastarjelice knjiškoga podrijetla koje objašnjava "utjecajem dubrovačkih pisaca i još izravnijim utjecajem Vitezovićeve Kronike" te frazeološke izraze različite vrste i podrijetla, npr. svezati sablje; otvoriše se bajraci po Sarajevu; kadiji digoše uši 'učiniše ga pozornim' (65) (Benić). Jednako tako navodi i imenice muškoga roda tipa nomina agentis, koje se tvore sufiksom -telj i koje su se "proširile preko crkvenih tekstova": odkupitelj, osloboditelj, podilitelj, činitelj, služitelj (Dobretić 19).

U vezi s leksikom Pranjković iznosi još jedno zanimljivo zapažanje: da se u Lašvaninovu ljetopisu “[... ] susreće dosta riječi koje svojom neobičnošću, rijetkošću i/ili tvorbenom efektnošću, a nerijetko i kontekstualnom prikladnošću doimaju poput novotvorenica (među njima bez sumnje ima i 
onih koje to doista i jesu)": samodržac, usilnik, pripovisnik, ljudomorstvo, staroča (patrijarh), haračnik, kraljomorac, rupar ('rudar'), starovirac, uzdržatelj i dr. (37) i mnogi drugi.

Tako iscrpnu i sustavnu analizu jezika franjevaca Bosne Srebrene mogao je napisati samo vrstan filolog, usto i dobar poznavalac kulturnih, vjerskih, društvenih i povijesnih prilika u kojima su franjevački tekstovi nastajali. Da je riječ o filologu koji izvrsno poznaje franjevačku književnu ostavštinu potvrđuje i činjenica da Pranjković, unatoč opsežnosti korpusa, uspostavlja poveznice među franjevačkim piscima i njihovim tekstovima. On često međusobno uspoređuje njihov jezik, stil i leksik, primjerice Lašvaninov i Benićev:

Kod Benića se susreće velik broj orijentalizama, talijanizama i latinizama, Lašvanin je u tome suzdržan, prema Beniću je gotovo purist; ${ }^{5}$ Lašvaninov je stil služben i neutralan, budući da je objektivan izvještač o događajima, a Benić ima bujnu maštu pa događajima o kojima govori koješta i pridodaje, ${ }^{6}$ Lašvanin je ikavac jer u njegovu jeziku prevladavaju ikavizmi, Benić ima puno (i) jekavizama pa i hiperjekavizama, npr. mijer, umijeriti, okvijer, koji su tipični za govore sutješkog kraja; ${ }^{7}$ U Lašvaninovu (pak) jeziku ima i šćakavizama: pušća, kršćenje, šćeta, ali naporedo i ikavskih oblika tipa navištuje, dopuštenje, krštenje. $^{.}$

Pranjković upućuje i na "preplitanje jezičnih i stilskih osobitosti" koje su pojedini autori preuzimali od prethodnika ili važnijih pisaca. Primjerice skreće pozornost na Benićeve starije padežne oblike "koji su (bar dijelom) rezultat i utjecaja Vitezovićeve Kronike": s dvimi kćerami; bog pisnikov; ljudem posta pribivalište; nad Židovmi, protiva Rimljanom; na osičkih mostovi (26).

Kao što je već spomenuto, ovim kratkim izlaganjem u čast profesoru Pranjkoviću autor je ovoga teksta želio istaknuti njegov velik doprinos izučavanju jezika franjevaca. Zahvaljujući njegovu znanju, akribiji i predanosti struci ti radovi, osim znanstvenih spoznaja, omogućuju i izoštreniji filološki pogled u veliku kulturnu baštinu i danas arhaičan i "neobičan", ali po mnogočemu i lijep jezik ljetopisa i teoloških i književnih tekstova franjevaca Bosne Srebrene.

\footnotetext{
Ivo Pranjković, Hrvatski jezik i franjevci Bosne Srebrene, str. 23.

ibid: 23.

ibid: 24.

ibid: 25.
} 


\section{LITERATURA}

Bosanski franjevci (prir. Karamatić, Marko). 1994. Zagreb: Erasmus.

Brozović, Dalibor. 1973. Uloga bosanskohercegovačkih franjevaca u formiranju jezika hrvatske književnosti i kulture - od Divkovića do fra Grge Martića. Godišnjak Instituta za izučavanje jugoslovenskih književnosti, knj. II. Sarajevo, 35-53.

Džaja, Matko Srećko. 1972. Povijesni okviri djelovanja bosanskih franjevaca 19. stoljeća. Godišnjak Instituta za izučavanje jugoslavenskih književnosti, II. Sarajevo, 25-34.

Kuna, Herta. 1977. Talijansko-latinski uticaji u jeziku bosanskohercegovačkih franjevaca 17. i 18. v. Naučni sastanak slavista u Vukove dane, VI. Beograd, 37-385.

Pranjković, Ivo. 2000. Hrvatski jezik i franjevci Bosne Srebrene. Zagreb: Matica hrvatska.

Pranjković, Ivo. 2005. Jezik bosanskih franjevaca. Jezik u Bosni i Hercegovini (ur. Svein Mønnesland), Sarajevo, 159-171.

Pranjković, Ivo. 2008. Franjevačko spisateljstvo na hrvatskome jeziku. Zagreb: Hrvatska sveučilišna naklada.

\section{SUMMARY}

\section{IVO PRANJKOVIĆ ON THE LANGUAGE OF BOSNIAN FRANCISCANS}

This paper discusses Ivo Pranjković's scholarly research on the language of Bosnian Franciscans. Pranjković's articles and books about the linguistic and stylistic characteristics of the chronicles and literary works written in Croatian by Bosnian Franciscans are considered by the author of this paper to be an immense and valuable contribution to the Croatian philology and to the study of the Croatian standard language tradition, which until the end of the nineteenth century was almost exclusively tied to the activities of the friars of the Franciscan province of Bosna Srebrena.

Key words: Ivo Pranjković, the language of Bosnian Franciscans, Franciscan literature in Croatian 